\title{
Danielis ludus: Transforming Clerics in the Twelfth Century
}

\begin{abstract}
A twelfth-century so-called liturgical drama (preserved in a unique copy of the thirteenth century, preserved in British Library, London), the Danielis ludus (Play of Daniel), based mainly on chapters 5 and 6 from the Book of Daniel has been much discussed in scholarship. It has been seen by scholars, not least Margot Fassler, as a (music) drama intended to establish a role model for young clerics in connection with ecclesiastical attempts at reforming the celebrations for New Year's in Beauvais, the so-called Feast of Fools. In this article, with consideration also of a recent discussion of the New Year's liturgy, I suggest to understand the Danielis ludus as a liturgical ritual transforming the (corporate) identity of the young clerics who were, undoubtedly, involved in its performance.
\end{abstract}

\section{Introduction}

In the introduction to this issue, the editors raise the following question about medieval liturgy: "What are the underlying cognitive assumptions / processes that make the formation of a new self (homo novus) a conceivable project, with actual effects?" First of all, this raises another question, did liturgical ceremonies have such actual effects on its participants, and if so to what extent? It is, of course, very difficult to know. Historically, we know the broad outline of a history of Christian conversions in terms of how Christianity spread from its early small group of Jesus-adherents, believing in Christ's resurrection, to gradually larger and larger groups of people around the Mediterranean in the course of the first century. Also, our knowledge of Christian martyrdom during persecutions occurring at times here and there in the Roman Empire during the first three centuries makes it clear that there was indeed transformative power in Christianity for individuals. But we also know how power politics became involved in the expansions of Christendom over the following centuries, after the Constantine turn of the early decades of the fourth century. Mass conversions, as for instance of Saxons under Charlemagne's warfare during the last decades of the eighth century, may question ideas of the religious transformations of individuals and raise questions as to how much or how deeply the religious services carried out in such regions was able to affect these people. However, we also possess sources, such as the Old Saxon Heliand of the ninth century, a poetically rewritten Gospel harmony, which tells the New Testament stories about Jesus, his disciples, his passion and resurrection in ways which reflect the particular cultural circum- 
stances of the people it addresses. This gives impressions at least of attempts among missionaries or the newly converted to make the Christian message culturally understandable. ${ }^{1}$

\section{Medieval Liturgy and Liturgical Enactments}

The way Roman liturgy was appropriated by the Carolingians is characterized by two opposite tendencies. Carolingian kings strongly supported this process during the eighth and ninth centuries, among them not least Charlemagne, reflecting the overall strategy of the Carolingian rule to "create a harmonious and Christian whole of a disparate realm". ${ }^{2}$ On the one hand, the actual import of Roman liturgical text, song and ceremonial ensured authority, authenticity and sacredness, correctness of the cult in the view of the Carolingians. On the other hand, the freedom with which the Carolingians in practice handled the materials they imported shows their interest in establishing a perceivable meaning of the rituals, probably less for the congregations in general who may rarely have been able to appreciate the intricate and intellectual details, but at least for the clergy who performed the ceremonies. The Carolingian development of the chant, involving also the practice of musical notation, a hugely important tool for the further development of musical composition, as well as other new creative efforts in the composition of tropes, textual and musical additions to traditional items especially of the mass demonstrate such a striving for overall liturgical meaningfulness. Traditional liturgical items were thus to a high extent provided with a theological commentary, in a poetic and musical form. These additions were locally determined, as opposed to the items taken over from the Roman mass, although tropes and also sequences, another poetic addition to the mass which took its beginning in Central European monasteries, were often widely disseminated. ${ }^{3}$

Through the vast corpus of new musical and poetic items, which supplemented what had been appropriated from Roman liturgy, a combined theological and artistic, liturgical (and devotional) compositional culture was developed in Carolingian (and subsequent) monasteries and their scriptoria. This involved what from a modern (anachronistic) vantage point may be characterised as artistic experimentation with liturgical genres; at the time nothing points in the direction of a separation between artistic and devotional or cultic purposes of the poetry and music composed for the liturgical rituals.

The described development in the Carolingian and following period is also a background for what in scholarship has generally been termed the liturgical drama, a highly problematic notion, as modern scholars have pointed out. ${ }^{4}$ Briefly, and in passing, I must mention that several of the notions, which I use in this article, mainly in order to avoid a long and complex discussion, involve more or less similar problematics of anachronistic terms, which have been applied in modern times to performative events and their representations in medieval sources. This also concerns e.g. "liturgy" and "ritual". 5 Within the narrow framework of this essay, however, I believe that the intended meaning cannot easily be misunderstood.

\footnotetext{
${ }^{1}$ See Murphy 1992 and Murphy 1989.

${ }^{2}$ McKitterick 2008, 378-79.

${ }^{3}$ Petersen forthcoming a. See also Iversen 2010, and Page 2010, esp. Chapters 14-19.

${ }^{4}$ Petersen 2009a, Petersen 2017, Norton 2017.

${ }^{5}$ Petersen 2007a, esp. 89-92.
} 
Many theatre scholars and liturgists in the nineteenth and twentieth century believed that European drama evolved in the context of medieval liturgy during the tenth, eleventh and twelfth centuries from the short sung dialogues between angels and the women at the grave of Jesus in liturgical ceremonies for Easter morning. This idea gave rise to the notion of "liturgical drama". By contrast, much recent scholarship has understood ceremonies, which were frequently described as 'dramatic' by previous scholarship, as a liturgical experimentation attempting to represent and re-enact biblical and other sacred narratives with a liturgical and ritual purpose. In such a view, these new techniques in ceremonies around the year 1000 and the following centuries did not have any theatrical purpose (in a modern sense) but were intended to reinforce or amplify what liturgical ceremonies were meant to do in all cases. They had a ritual purpose (in a modern sense): they were to help transform the participants in the ceremony in their hearts so as to bring home or reconfirm the fundamental message, the belief in Christ's love and salvation. ${ }^{6}$

As already mentioned, the first attempts at such liturgical re-enactment concerned the narrative of Christ's resurrection, the message given to the three women by an angel (or two) at Christ's grave on Easter morning. These were quite short dialogues enacted in a way so that they evolved out of the Easter morning liturgy and led back to the fundamental liturgical praise of the resurrection. More complicated (and longer) forms of biblical enactments, where also notions of theatricality are clearly more relevant, came about especially from the twelfth century in continental Europe, when also passion plays began to be composed, in Latin mixed with vernacular languages, and also plays about St. Nicholas were composed. ${ }^{7}$

\section{"Danielis ludus" and the Feast of Fools}

The Danielis ludus, the Play of Daniel, to which I shall now turn, is part of what at this time may be thought of as a genre of liturgical (and biblical) enactment. Although the single manuscript, in which it is preserved (British Library, London, Egerton MS. 2615 f. 95r-108r), is dated to the thirteenth century, the play is thought by many scholars to have been composed in the twelfth century. ${ }^{8}$ At this time, such larger "liturgical dramas" may even be said, at least in some places, to be on their way to a separate life, constituting perhaps a dramatic subgenre of their own, no longer necessarily integrated into one specific position within a liturgical ceremony. Generally, we have no explicit knowledge of when and how these larger plays were performed. Our knowledge mostly comes only from the preserved manuscripts (which rarely give such information), except for very occasional, circumstantial and often unclear references to liturgical excesses. In any case, the texts show definite affinities to the liturgy and are in a broader sense inseparable from it. ${ }^{9}$

The Danielis ludus is based mainly on chapters 5 and 6 from the Book of Daniel. It is one of the medieval liturgical dramas most frequently discussed in modern scholarship, and it is also one of the few such ceremonies which has been re-performed and recorded several times.

\footnotetext{
${ }^{6}$ See Flanigan 1974, Flanigan 1996, Flanigan 2014, Kobialka 1999, Petersen 2009b, Petersen 2017.

${ }^{7}$ See Flanigan 1985 .

${ }^{8}$ Dronke 1994, 119, Harris 2011, 113, Emmerson 1996, 45, Bevington 1975, 137, cf. Fassler 1992, 82-85. The full manuscript is accessible online at the British Library website: http://www.bl.uk/manuscripts/Viewer.aspx?ref=egerton_ms_2615_fs001r.

${ }^{9}$ Flanigan 1985, 14-15, Petersen 2017 and Petersen forthcoming b.
} 
It renders two narratives (from each of the two mentioned biblical chapters): first the story of Daniel's interpretation of the writing on the wall, predicting the fall of King Belshazzar, which immediately occurs, even though Belshazzar accepts what Daniel tells him, heeding the advice to return the vessels his father had taken from the temple, and even honouring Daniel. This leads into the second part, the arrival of the new king, Darius the Mede who, after having overthrown King Belshazzar, is advised to bring Daniel to the court to give him a high position. While Daniel accepts, other counsellors grow envious and convince the king to accept a new law forbidding all worship except that of the king, a law targeted against Daniel who as a devout Jew worships God, the creator of all. The king had not realised the purpose of the law, and is now forced, against his will, to condemn Daniel to the lions. Daniel, however, is miraculously protected by angels in the den. At this point, the play incorporates an episode from the Apocryphal additions to the Book of Daniel in which Daniel (once again) was sentenced to the lions' den, this time staying there for six days (Dan 14:30-42). ${ }^{10}$ In the play the brief narrative of the prophet Habakkuk bringing food to Daniel in the den (Dan 14: 32-38) was inserted into the narrative of Daniel's overnight stay in the den in the narrative from Dan 6. The next morning the king finds Daniel alive, he reinstates Daniel in his position, condemns the evil counsellors to death and declares that all should worship Daniel's God.

In the play, all this is not just presented in a linear chronological narrative. Numerous times, from the very beginning to the very end, songs interrupt the narrative, commenting and summarising the events. In two cases songs refer explicitly to an ongoing celebration of the birth of Christ, which (for this reason) presumably constituted the liturgical context of the performance of the play. The play concludes with the Te deum.

Danielis ludus is copied in a manuscript together with one of the few preserved medieval Circumcision offices, a full office, i.e. containing the full divine office as well as the mass for New Year's Day. This office has also received popular designations, among them officium stultorum, in English the Feast of Fools. The New Year's feast was part of four particular feast days for clerics, feast days which were part of the normal Christian calendar. St Stephen's Day (26 December) for the deacons; the Feast of St John the Apostle on 27 December for the priests, the feast of the Holy Innocents (the children martyred in Bethlehem by King Herod, cf. Matt 2: 16-18) on 28 December for the boys of the schola. Celebrations on these Saints' days included processions of deacons on 26 December, priests on 27 December, and children on 28 December, and it appears that these groups had particularly prominent roles in the liturgy of the day. Liturgical sources from the tenth through the thirteenth centuries give more details, but it is important to note that these feasts were regular liturgical feasts, just with a certain emphasis on the mentioned clerical groups. ${ }^{11}$ New Year's Day on January $1^{\text {st }}$ was another feast for a clerical group, this time the subdeacons, a group which, according to the strict and conservative twelfth-century Parisian liturgical commentator Iohannes Belethus, had an uncertain status at the time, sometimes "counted among the sacred orders, sometimes not". For this reason, Belethus contends that it is celebrated on different days in different

\footnotetext{
${ }^{10}$ I refer to the Vulgate Bible (in Latin) and its (early modern) Douay-Rheims translation, Kinney 2012.

${ }^{11}$ See Arlt 1970, Darstellungsband, 38-51, Fassler 1992, 74-77, Harris 2011, 66-67.
} 
places, and "might be celebrated with a confused office" (officio celebretur confuso), an expression which should possibly rather be translated as a "mixed office". ${ }^{12}$

Belethus' notion of an officio confuso may be interpreted variously. Wulf Arlt writes that while this may point to abuses, as suggested by some scholars, it may also simply have to do with his conservative stance which may have deemed an office confused just on the grounds of rich additions of new songs for the liturgy. ${ }^{13}$ Others, including Margot Fassler, have made much more out of Belethus' phrase, combining it with other sources criticising un-ordered behaviour at the time. She believes the preserved full orders for the Circumcision office from Beauvais and another one from Sens, closely related to the Beauvais office, to be reformed orders. Fassler points to "indications that reformers and other high-minded churchmen were fed up with the Feast of Fools and other popular displays of misrule during the Christmas Octave in Paris and elsewhere". ${ }^{14}$

Fassler's interpretation of the Danielis ludus has its basis in this historical context and the fact that the only preserved manuscript of the Play of Daniel was copied in the same manuscript as the Beauvais Office of the Circumcision. Both were written by the same hand and the music similarly notated by the same hand. ${ }^{15}$ Thus, it is a very natural assumption that the Danielis ludus was a play for the Feast of Fools, although this is by no means a proven fact, since putting things together in a manuscript could be done for many different reasons. There are, however, also some textual and musical connections between the Circumcision office and the Play. Fassler takes her point of departure in the mentioned idea that the preserved Beauvais Circumcision office in the Egerton manuscript constitutes a reformed office; however, since we have no preserved earlier direct sources to the Circumcision office in Beauvais this is a conjecture. She then interprets the play as intending to present the figure of Daniel as a role model for the young clerics, the subdeacons, who were the rulers of this feast (i.e. those with a particularly pronounced role in the offices for the day) on 1 January in Beauvais (and also in Sens). (In other places the subdeacons' feast could be celebrated on Epiphany, 6 January, or even a week later, on the Octave of Epiphany).

Fassler's interpretation is supported also by musical analyses, pointing out for example many musical borrowings from liturgical chant. Fassler argues convincingly, musically as well as textually, that the emphasis of the play on the stories about the devout and hero-like Daniel are not only for entertainment but presented also with a devotional and edifying aim. The young and pious Daniel is a role model for the youths of Beauvais, miraculously interpreting the writing on the wall, just as he is miraculously guarded by angels when he is later condemned to the lions' den, and there even miraculously fed by the prophet Habakkuk as already mentioned.

\footnotetext{
${ }^{12}$ Arlt 1970, Darstellungsband, 40, Fassler 1992, 74, and Harris 2011, 66-67. Fassler translates "confused office," Harris "mixed office". The different renderings are significant for their understandings of the Feast of Fools, cf. Max Harris' rewriting of the history of the Feast of Fools, Harris 2011, Part II, 65-127, and his detailed, critical as well as appreciative discussion of Fassler's article, 115-120. See further below.

${ }^{13}$ Arlt 1970, Darstellungsband, 42.

${ }^{14}$ Fassler 1992, 77.

${ }^{15}$ Arlt 1970, Darstellungsband, 26, Fassler 1992, 66. For the Circumcision office from Sens, see Harris 2011, 98-107. The office is edited in Villetard 1907.
} 
The prologue of the play clearly states that it was composed, put together, by youths of Beauvais, or a youth from Beauvais, most likely by the young clerics or students from the cathedral school in Beauvais:

Ad honorem tui, Christe, Danielis ludus iste in Belvaco est inventus, et invenit hunc iuventus.

[In your honour, Christ, this play of Daniel was composed in Beauvais - it was the young who composed it]. ${ }^{16}$

As mentioned, Wulf Arlt was more cautious in his interpretation of the twelfth-century Feast of Fools. Recently, Max Harris in his celebrated book Sacred Folly: A New History of the Feast of Fools (2011) has pointed out that we have no evidence for any of the traditional accusations about misrule or abuses during the liturgical offices for the subdeacons' feast, i.e. the office for New Year's Day in Beauvais. In connection with Margot Fassler's interpretation of the Play of Daniel, Harris writes:

Although Fassler's identification of the Play of Daniel with the Feast of Fools is persuasive, her portrayal of the Feast of Fools should be approached with considerable caution. ${ }^{17}$

Still, he accepts her fundamental claims, with a small modification:

Rather than supposing that the Play of Daniel was part of an ongoing effort to reform the Feast of Fools in Beauvais, we can imagine that the play, like the liturgical feast itself, was designed as a rival attraction to competing Kalends games. Indeed, the play was able to go one step further than the office of the Circumcision alone. By devoting the ample resources of the church to the staging of the Play of Daniel, the 'young men' of Beauvais cathedral were simultaneously able to outperform the secular New Year games and, in the dramatic narrative, condemn them as pagan. ${ }^{18}$

The mentioned scene where Habakkuk brings food to Daniel in the lions' den was understood by Margot Fassler as "an allusion to the sacramental meal served at Mass," even though it has "comic overtones - the prophet is dragged in by the hair as the lions mill hungrily about". She noted how Daniel's music here (as also in some other places) brings "the style of liturgical chant to mind". ${ }^{19}$

Richard Emmerson has discussed the Play of Daniel in the context of an ongoing struggle between the kings of France and the bishop-counts of Beauvais, who were vassals of the king and "closely associated with the royal family". Emmerson points out that as "peers of the realm, the bishop-counts of Beauvais were supportive counsellors of the king, yet they jealously maintained their independence from Paris," protecting their "hard-won and longstanding local rights". ${ }^{20}$ The chapter, thus, thought highly of its own importance, something not least reflected in the building programme for the huge new cathedral, built a few decades into the thirteenth century. Already in the 1180 s, however, extensions of the old cathedral

\footnotetext{
${ }^{16}$ Dronke 1994, 120-121

${ }^{17}$ Harris $2011,115$.

${ }^{18}$ Harris 2011, 116.

${ }^{19}$ Fassler 1992, 95.

${ }^{20}$ Emmerson 1996, 45.
} 
(the so-called Basse-Oeuvre) were carried out, and, as Andrew Tallon points out, even the old cathedral "was once grand in its own right". ${ }^{21}$ Tallon discusses the building history during the possible timeframe for the composition of the Play of Daniel, i.e. approx. the mid-twelfth century up to c. 1230 (the manuscript was copied between 1227 and 1234). ${ }^{22}$ In Tallon's view it is impossible to conclude which of the buildings were the original home of the play, but points out that the play presumably would have continued to be performed in the cathedral, and thus may actually have been performed in more than one of the constructions during the decades around $1200 .^{23}$

The play has numerous smaller (and some big) roles and presumably students and lower clergy from the cathedral and its schola would have carried out these roles, some of which require high musical skills. Undoubtedly, the canons of the cathedral would have been present for such a performance and, if the assumption of an association with the New Year's feast is correct, which I believe, it seems very likely that the occasion would have been open also to a broader congregation, although probably mainly intended to impress its message on the young clergy. ${ }^{24}$

\section{Reading the "Danielis ludus" in a new light}

In recent publications, I have discussed the nature of the liturgical experimentation that evolved through liturgical enactment, beginning with clearly liturgically embedded resurrection ceremonies, the so-called visitatio sepulchri ceremonies, already mentioned above as the earliest preserved such enactments, the first of which are found in liturgical manuscripts of the tenth century. I have argued that some visitatio sepulchri ceremonies around 1200 function as ways of ritually celebrating and re-confirming the doctrines of the real presence and the (at the time) relatively new doctrine of transubstantiation, and are thus not primarily to be understood as representations of the resurrection narratives for their own sake. ${ }^{25}$

My work on this has been inspired not least by Michal Kobialka's claim that the liturgical drama in some ways came about in parallel to the development in Eucharistic understanding during the centuries between the ninth century and the fourth Lateran Council where the notion of transubstantiation was re-confirmed. ${ }^{26}$ The ceremonies I have studied in this context are specific examples that corroborate his theory. But, indeed, all the visitatio sepulchri ceremonies, at this time, were sacred signs of what was considered the most holy event in History, that is they were sacraments, as that word was used before c. 1130. Up to the early 1100s the understanding of "the sacred" did not yet distinguish clearly between specific ecclesiastical sacraments, i.e. the church's means of salvation on the one hand, and sacred signs more generally on the other. In the 1130s, a new development in sacramental understanding - first through Hugh of St Victor, who was an Augustinian canon connected to ideals of the Gregorian papacy, followed over the next decades by Peter Lombard - came to make a sharp distinction between sacraments and sacred things that were not sacraments. From that time on-

\footnotetext{
${ }^{21}$ Tallon 2015, 207.

${ }^{22}$ Emmerson 1996, 45; Tallon 2015, 210 (and n. 17).

${ }^{23}$ Tallon 2015, 207 and 217.

${ }^{24}$ Cf. Fassler 1992, 97-98, and Tallon 2015, 215.

${ }^{25}$ Petersen 2017, 16-22, and Petersen 2007b, 336-348.

${ }^{26}$ Kobialka 1999, Introduction, 31-33. See Petersen 2017 and Petersen forthcoming b.
} 
ward, only the seven well-known sacraments remained as "proper" sacraments and thus left such experimental genres as sacred biblical enactments outside of the "really sacred," which then came to occupy the main interest of the theologians. ${ }^{27}$

My point is that these not quite so sacred ceremonies, which were not even part of a liturgical canon, were able to develop in a more free way, thus sometimes staying within a liturgical realm, while they were at other times rather understood as devotional entertainment. Much later, such a development lies behind the establishing of the English mystery cycles of the fourteenth and fifteenth centuries. I believe that this makes it possible to understand the historical and diachronic connection between medieval liturgy and early modern theatre, and it makes it particularly interesting to look for traces or the cultural memory of sacramental origins in ceremonies or plays of the twelfth century. ${ }^{28}$

Margot Fassler read the Habakkuk scene of the Danielis ludus as alluding to the Eucharist. I agree, but I believe that there is more to it than just an association. A number of liturgical dramas, including the Danielis ludus, constitute a ritual with the aim to impress piety and activate devotion in the clerics who perform and, possibly, also in those who were otherwise present and at numerous points during the play were drawn in, not as spectators or audience, but as participants, as a congregation. A case in point are the songs that frame the actual action. As mentioned already, such songs frame the whole piece, suggested already by the pious formulation of what appears as the prologue to the play (quoted above), and explicitly involving the congregation in the celebration of Christmas in a processional song (conductus) accompanying Daniel when he goes to King Darius. Here they sing "joyously let us celebrate the Christmas feast". ${ }^{29}$ Slightly earlier in the play, in a processional song bringing back the holy vessels, which King Belshazzar had taken from the temple, Daniel is presented explicitly as a prophet. ${ }^{30}$ At the end of the play, he prophesies the birth of Christ and is followed by an angel who sings a liturgical hymn announcing the birth of Christ, before the play ends with the singers intoning the Te deum as a proper liturgical ending to the play. ${ }^{31}$ In the play, Daniel resurrects from the lions' den as a type of Christ coming out of the grave Easter morning. Thus Daniel's greeting to King Darius who has come to see whether Daniel's God has in fact saved him, "King, live for ever!" (a greeting appearing several times during the play) might be understood not only as an indication of his own survival but also as a praise to God, or Christ. $^{32}$

In the short scene with Habakkuk, Daniel appears as a type of a Christian receiving the Eucharist. He responds correspondingly with praise and thanks, and, as already noted with a reference to Margot Fassler, with music alluding to liturgical chant:

Habakkuk:

Surge, frater, ut cibum capias; tuas deus vidit angustias; deus misit - da deo gratias qui te fecit.

[Rise, brother, to take your food; God has seen your anxiety; God has sent this: give thanks to God who made you.]

\footnotetext{
${ }^{27}$ Petersen 2015, 193-196, and Petersen 2017, 19-21.

${ }^{28}$ Petersen forthcoming $b$.

29 “congaudentes celebremus natalis sollemp/nia”, Dronke 1994, 134-135.

${ }^{30}$ Dronke 1994, 130-131.

${ }^{31}$ Dronke 1994, 142-143.

32 “Rex, in eternum vive!” Dronke 1994, 140-141. See also Petersen 2003, 307.
} 
Daniel:

Recordatus es mei, domine! Accipiam in tuo nomine - alleluia!

[Lord, you have remembered me! I shall accept it in your name - alleluia! ${ }^{33}$

In a previous publication on the Danielis ludus, I have pointed to the ritual technology involved in the composition of the play: the construction of the play is better understood in terms of its ritual function than through its narrative presentation, which in some instances is odd. $^{34}$ There is, however, no consensus about the term among modern scholars. My usage of the term is informed by the work of Clifford Geertz and Clifford Flanigan, combined with the way church fathers and medieval as well as later theologians have thought about the meaning of liturgical action. In the context of medieval liturgy, I conceive of it as a meeting place between man's life and thought on the one hand, and a Christian understanding of the world as expressed in fundamental Christian doctrines on the other. This meeting place is esta-blished in prayers and liturgical actions, as also suggested by the traditional tag, lex credendi - lex orandi, which was formulated already in late Christian Antiquity, likely by Prosper of Aquitaine in the fifth century. ${ }^{35}$ In a ritual, the world as experienced and the world as imagined meet each other, turning out to be the same, to paraphrase Clifford Geertz' famous summary of what a ritual accomplishes for its participants. ${ }^{36}$

When Daniel enters the lions' den, condemned to death by King Darius, who has been tricked into doing this by conspirators, Daniel first sings a lament, which invites pity and identification with his terrible fate. ${ }^{37}$ When he actually enters the den, he sings some strange lines, claiming not to be guilty, "huius rei non sum reus", "I am not guilty in this case". 38 Narratively speaking, this is clearly incorrect, since it was his own decision not to obey the law the conspirators made the king issue. However, in a liturgical celebration, praising Daniel as a type of the true Christian, a saint, a role model for the youth, which is clearly a main point of the whole performance, Daniel can obviously not be considered as "guilty". 39

My point is that the play oscillates between a narrative representation of the biblical story and elements of a ritual mode, a mode of celebration or even liturgical condensation. Here Daniel is no longer just a protagonist in a well-known narrative, but a sacred figure to be followed, not just admired; he seems to be a sacramental figure moving the congregation to experience his sacred priesthood, which can lead them to Christ. As he enters the lions' den, the congregation is made to follow him into his prayer for God's mercy, he is the priest, not guilty, not sinful, and they are led to true piety through his saintly figure's sung prayer. Similarly, what has been seen as a comic scene in which the reluctant Habakkuk is led to Daniel in the lions' den by his hair is suddenly transformed to serious sacramentality when the saintly

\footnotetext{
${ }^{33}$ Dronke 1994, 140-141, cf. Dan 14:37.

${ }^{34}$ Petersen 2003, 304-306.

${ }^{35}$ For a historical account of this 'tag' and its reception throughout Christian theology, see Wainwright 1980, 218-283.

${ }^{36}$ Geertz 1966, 28, see also Flanigan 1996, 10, and Petersen 2015, 192-193.

${ }^{37}$ Dronke 1994, 138-139. See Margot Fassler 1992, 94, characterising it as "a moving testament against the pride and misguided leadership of king Darius" and further stating that it "depicts a historical type of Christ feeling the pangs of mortality".

${ }^{38}$ Dronke 1994, 138-139.

${ }^{39}$ The prayer continues, see Dronke 1994, 140-141, and see the discussion in Petersen 2003, 304-306.
} 
Daniel receives God's life-giving food, leading the congregation to see and hear words that emulate what is said and done at the Eucharist.

It is instructive to compare the Danielis ludus to the more or less contemporary (definitely twelfth-century) Historia de Daniel representanda (preserved without music) by Hilarius, a student of Abelard, explicitly intended for Vespers or Matins. The two Daniel plays are, unsurprisingly, narratively very close, employing exactly the same biblical episodes. It has been discussed whether one was dependent on the other and, in that case, which is the earlier. ${ }^{40}$ What is interesting in the present context is that Hilarius' play, while narratively very close to the Beauvais ludus, has none of the ritual technology to which I draw attention in the Danielis ludus. Hilarius' play is much more straight-forward in its narrative representation. The liturgical embeddedness of Hilarius' play is explicitly noted in the manuscript, while a liturgical embeddedness is manifested more indirectly in the Danielis ludus, as already pointed out. However, there is much less use of liturgical connotations and identification in Hilarius' text than in the Beauvais play, confirming the breadth of what was possible within this liturgicodramatic tradition at this point in time. ${ }^{41}$

As mentioned above, in some short visitatio sepulchri ceremonies at Eucharistic processions, Christ's resurrection is enacted as a sign, a sacrament (in the early use of the word) of the efficacy of the Eucharist. In the Danielis ludus, the episode of Habakkuk bringing food to Daniel similarly functions as a sign of, or a sacrament of the Eucharist (in this same earlier use of the word). Pointing to the Eucharist in this way is in itself a sign, a sacrament of Daniel's miraculous survival, because God remembered him. For the congregation present at a performance of the play (of which we have no records), this is a sign of how they can also survive and live as humans, because they are also remembered by God, as they are told in the Eucharist.

Therefore, I suggest, the Danielis ludus does much more than establish a narrative model for the young clerics and the youths of Beauvais. It does that too, of course. But even more, in its artful play with liturgical and narrative elements, textually as well as musically, the latter coming to the fore in the musical appropriations of liturgical chants as documented by Fassler, the Danielis ludus establishes moments of dense sacramental tension. In these moments, the performing clerics as well as those merely present, are transposed into a congregation, intended to actually experience themselves as a congregation, sacramentally engaged in what is happening, becoming part of it, not just as spectators, not just as passive outsiders. Through ritual technology they are engaged as Daniel's friends, as those who celebrate Christmas together with Daniel, and for whom he becomes a priestly leader in those moments. If the play was, indeed, performed during an office, for instance at Matins, it might have coaxed the congregation into the role of spectators, amusing them by the representation of the narratives, and then, in such loaded moments, capturing them by bringing them back into ritual seriousness and devotional intent.

\footnotetext{
${ }^{40}$ See Fassler 1992, esp. 86-87; Dronke 1994, 119, and also Petersen 2003, 305-306.

${ }^{41}$ Hilarius' play is edited in Bulst and Bulst-Thiele 1989, 48-59. Their volume also includes a textual edition of the Danielis ludus, as well as a musical transcription by Mathias Bielitz, based on Charles-Edmond de Coussemaker's transcription in the first edition of medieval music dramas with music (published in 1860).
} 
If our own modern experience of this old text and music can bring us a hint of such a ritual experience, then we may be persuaded that it might have worked at the time, at least for some, and that similar experiences, mutatis mutandis, may turn out to work for us.

Nils Holger Petersen

University of Copenhagen

nhp@teol.ku.dk 


\section{BIBLIOGRAPHY}

\section{Textual (Printed) Sources}

Arlt W. 1970: Ein Festoffizium des Mittelalters aus Beauvais in seiner liturgischen und musikalischen Bedeutung, 2 vols. [Darstellungsband; Editionsband], Köln.

Bevington D. (ed.) 1975: Medieval Drama, Boston.

Bulst W. and M.L. Bulst-Thiele (eds.) 1989: Hilarii Aurelianensis versus et ludi epistolae, Ludus Danielis Belouacensis, Leiden.

Danielis ludus, The Play of Daniel (Latin/English), in Dronke, Nine medieval Latin plays, 110-146, musical transcription in Ogden 1996, 91-116, facsimile edition in Ogden 1996, without page numbers.

Dronke P. (ed.) 1994: Nine medieval Latin plays, Cambridge.

Villetard H. (ed.) 1907: Office de Pierre de Corbeil (Office de la Circoncision) improprement appelé "Office des Fous", Paris.

\section{Secondary Literature}

Emmerson R.K. 1996: "Divine Judgment and Local Ideology in the Beauvais Ludus Danielis", in D.H. Ogden (ed.), The Play of Daniel: Critical Essays [Early Drama, Art, and Music Monograph Series, 24], Kalamazoo, MI, 33-61.

Fassler M. 1992: "The Feast of Fools and Danielis ludus: Popular Tradition in a Medieval Cathedral Play", in T.F. Kelly (ed.), Plainsong in the age of polyphony, Cambridge, 65-99.

Flanigan, C.C. 1974: "The Liturgical Context of the Quem Queritis Trope", Comparative Drama 8, Kalamazoo, MI, 45-62.

Flanigan C.C. 1985: "The Fleury Playbook, the Traditions of Medieval Latin Drama, and Modern Scholarship", in T.P. Campbell and C. Davidson (eds.), The Fleury Playbook: Essays and Studies, Kalamazoo, MI, 1-25.

Flanigan C.C. 1996: "Medieval Liturgy and the Arts. Visitatio Sepulchri as Paradigm", in E.L. Lillie and N.H. Petersen (eds.), Liturgy and the Arts in the Middle Ages. Studies in Honour of C. Clifford Flanigan, Copenhagen, 9-35.

Flanigan C.C. 2014: "Quid Quaeritis, O Clerici? A Review of Some Recent Scholarship on the Medieval Latin Music Drama”, in R.L.A. Clark (ed.), The Ritual Life of Medieval Europe: Papers by and for $C$. Clifford Flanigan [Romaid 52/53 (2014)], London, Ontario, 35-60.
Geertz C. 1966: "Religion as a Cultural System", in M. Banton (ed.), Anthropological Approaches to the Study of Religion, London, 1-46.

Harris M. 2011: Sacred Folly: A New History of the Feast of Fools, Ithaca and London.

Iversen G. 2010: Laus angelica: Poetry in the Medieval Mass (ed. J. Flynn; trans. W. Flynn), Turnhout.

Kobialka M. 1999: This Is My Body: Representational Practices in the Early Middle Ages, Ann Arbor.

McKitterick R. 2008: Charlemagne: The Formation of a European Identity, Cambridge.

Murphy G.R. 1989: The Saxon Savior: The Germanic Transformation of the Gospel in the Ninth-Century Heliand, New York-Oxford.

Murphy G.R. (ed.) 1992: The Heliand: The Saxon Gospel. A Translation and Commentary, New YorkOxford.

Norton M.L. 2017: Liturgical drama and the reimagining of medieval theater, Kalamazoo, MI.

Ogden D.H. (ed.) 1996: The Play of Daniel: Critical Essays [Early Drama, Art, and Music Monograph Series, 24], Kalamazoo, MI.

Page C. 2010: The Christian West and its Singers: The First Thousand Years, New Haven and London.

Petersen N.H. 2003: "Danielis ludus and the Latin Music Dramatic Traditions of the Middle Ages", in L. Dobszay (ed.), The Past in the Present [Papers Read at the IMS Intercongressional Symposium and the $10^{\text {th }}$ Meeting of the Cantus Planus]. Budapest and Visegrád. Budapest, 291-307.

Petersen N.H. 2007a: "Ritual and Creation: Medieval Liturgy as Foreground and Background for Creation", in S.R. Havsteen et al. (eds.), Creations: Medieval Rituals, the Arts, and the Concept of Creation, Turnhout, 89-120.

Petersen N.H. 2007b: "Representation in European Devotional Rituals: The Question of the Origin of Medieval Drama in Medieval Liturgy", in E. Csapo and M.C. Miller (eds), The Origins of Theater in Ancient Greece and Beyond: From Ritual to Drama, Cambridge and New York, 329-360.

Petersen N.H. 2009a: "The Concept of Liturgical Drama: Charles-Edmond de Coussemaker and Charles Magnin", in D. Saulnier, K. Livljanic and C. Cazaux-Kowalski (eds.), Lingua mea calamus scriba [Festschrift Marie-Noël Colette; Études Grégoriennes XXXVI], Solesmes, 305-314. 
Petersen N.H. 2009b: "Biblical Reception, Representational Ritual, and the Question of 'Liturgical Drama",, in G. Iversen and N. Bell (eds.), Sapientia et Eloquentia: Meaning and Function in Liturgical Poetry, Music, Drama, and Biblical Commentary in the Middle Ages, Turnhout, 163-201.

Petersen N.H. 2015: "Ritual. Medieval Liturgy and the Senses: The Case of the Mandatum", in H.H. Lohfert Jørgensen et al. (eds.), The Saturated Sensorium: Principles of Perception and Mediation in the Middle Ages, Aarhus, 181-205.

Petersen N.H. 2017: "Liturgical Enactment", in P. King (ed.), The Routledge Research Companion to Early Drama and Performance, London and New York, 13-29.
Petersen N.H. forthcoming a: "Liturgical Music and Drama", in D. Da Sousa Correa et al. (eds.), The Edinburgh Companion to Literature and Music, Edinburgh.

Petersen N.H. forthcoming b: "Medieval Latin Performative Representation: Re-evaluating the Stateof-the-Art", European Medieval Drama.

Tallon A. 2015: "The Play of Daniel in the Cathedral of Beauvais", in S. Boynton and D.J. Reilly (eds.), Resounding Images: Medieval Intersections of Art, Music, and Sound, Turnhout, 205-220.

Wainwright G. 1980: Doxology: A Systematic Theology, London. 